IZA DP No. 8406

Should the U.S. Continue Its Family-Friendly Immigration Policy?

Harriet Duleep

Mark Regets

August 2014

Forschungsinstitut zur Zukunft der Arbeit Institute for the Study of Labor 


\title{
Should the U.S. Continue Its Family-Friendly Immigration Policy?
}

\author{
Harriet Duleep \\ College of William and Mary \\ and IZA \\ Mark Regets \\ National Science Foundation \\ and IZA
}
Discussion Paper No. 8406
August 2014

\author{
IZA \\ P.O. Box 7240 \\ 53072 Bonn \\ Germany \\ Phone: +49-228-3894-0 \\ Fax: +49-228-3894-180 \\ E-mail: iza@iza.org
}

\begin{abstract}
Any opinions expressed here are those of the author(s) and not those of IZA. Research published in this series may include views on policy, but the institute itself takes no institutional policy positions. The IZA research network is committed to the IZA Guiding Principles of Research Integrity.

The Institute for the Study of Labor (IZA) in Bonn is a local and virtual international research center and a place of communication between science, politics and business. IZA is an independent nonprofit organization supported by Deutsche Post Foundation. The center is associated with the University of Bonn and offers a stimulating research environment through its international network, workshops and conferences, data service, project support, research visits and doctoral program. IZA engages in (i) original and internationally competitive research in all fields of labor economics, (ii) development of policy concepts, and (iii) dissemination of research results and concepts to the interested public.
\end{abstract}

IZA Discussion Papers often represent preliminary work and are circulated to encourage discussion. Citation of such a paper should account for its provisional character. A revised version may be available directly from the author. 
IZA Discussion Paper No. 8406

August 2014

\section{ABSTRACT \\ Should the U.S. Continue Its Family-Friendly Immigration Policy?*}

An ongoing debate is whether the U.S. should continue its family-based admission system, which favors visas for family members of U.S. citizens and residents, or adopt a more skillsbased system, replacing family visas with employment-based visas. In many ways this is a false dichotomy: family-friendly policies attract highly-skilled immigrants regardless of their own visa path, and there are not strong reasons why a loosening of restrictions on employment migrants need be accompanied by new restrictions on family-based immigration. Moreover, it is misleading to think that only employment-based immigrants contribute to the U.S. economy. Recent immigrants, who have mostly entered via kinship ties, are economically productive, a fact hidden by a flawed methodology that underlies most economic analyses of immigrant economic assimilation.

JEL Classification: J24, J15

Keywords: immigration, human capital, admissions policy

Corresponding author:

Mark Regets

National Science Foundation

4201 Wilson Boulevard

Arlington, VA 22230

USA

E-mail: mregets@nsf.gov

\footnotetext{
* We are grateful for helpful comments from Cordelia Reimers, David Reimers, Phanindra Wunnava, two anonymous reviewers, and the faculty and students of Middlebury College.
} 


\section{Should the U.S. Continue Its Family-Friendly Immigration Policy?}

\section{Introduction}

The demise of a national-origin quota system for U.S. immigration and its replacement in 1965 with a policy emphasizing family reunification opened the gates to a large and increasing flow of immigrants differing in national-origin composition from prior U.S.-immigrant flows. The resulting sea change in the quantity and character of U.S. immigration-like the waves of immigrants that arrived in the $19^{\text {th }}$ and $20^{\text {th }}$ centuries - has spawned concerns about the economic impact of the post-1965 immigrants, inspiring calls to reduce kinship-based admissions and increase immigrant employment skills. Congress is currently considering eliminating two kinship categories: the siblings of U.S. citizens and the adult children of U.S. citizens and legal permanent residents. Under the proposed system, those relatives could not obtain U.S. visas unless they possess specific job skills.

Two beliefs underlie the move towards a more skills-based system. One, family admissions serve humanitarian goals, only. Two, recent immigrants—most of whom were admitted via kinship ties—-harm national competitiveness. Both beliefs reflect a misunderstanding of how family-based immigrants contribute to the U.S. economy and why immigrants choose the United States as their preferred destination.

\section{Legislative History}

The Immigration Act of 1965, which eliminated country-specific quotas that discriminated against particular groups, introduced a system of restricted and non-restricted admission categories greatly favoring immigrants with family members in the United States (Figure 1). Under this law, 
in effect until 1990, spouses, minor children, and parents of U.S. citizens were admitted without regard to numerical limitations. Of the numerically restricted visas, $80 \%$ were reserved for the adult children and siblings of U.S. citizens (as well as their spouses and children) and for the spouses and children of legal permanent resident aliens. Only $20 \%$ of the numerically restricted visas were allocated to applicants based on their occupational skills, a classification embracing two components: workers, skilled and unskilled, in occupations for which labor is deemed scarce, and professionals, scientists, and artists of exceptional ability. ${ }^{1}$

[Figure 1 about here]

Thus, for nearly half a century, family unification has been the mainstay of the U.S. immigration system with a minority of admissions reserved for occupational skills. ${ }^{2}$ Nevertheless, a more skills-based admissions system has long been advocated by some immigration policy experts and many economists. A small move in that direction — buoyed by the belief that immigrants admitted via their occupational skills are more economically productive than kinship-based immigrants_occurred with the 1990 Immigration Act, which increased employment-based admissions but did not alter the essentially family-based nature of U.S. immigration (Lowell, 1996).

A call for a fundamental change in the U.S. family-based policy did occur in 1997: The U.S. Commission on Immigration Reform (mandated by the 1990 Immigration Act) recommended eliminating immigration preferences for the brothers, sisters, and adult children of U.S. citizens and legal permanent residents. In 2013, this recommendation re-emerged in the Senate comprehensive immigration reform proposal, with supporters arguing that to be

\footnotetext{
${ }^{1}$ This taxonomy is approximate.

${ }^{2}$ See Reimers (2013) and Enchautegui (2013) for insightful discourses on family immigration.
} 
economically competitive the U.S. must reduce kinship admissions and increase employmentbased admissions, particularly of the highly skilled.

A popular approach for increasing immigrants' skill levels is to expand existing visa categories designed to fill specific employment needs: the George W. Bush White House proposed replacing visa categories that allow U.S. immigrants to sponsor adult children, siblings, and potentially parents with visas giving preference to skilled workers sought by employers. Others advise reducing family immigration and increasing immigrant skill levels using general definitions of skill such as education or an ability to contribute to the U.S. economy.

Bolstering the push to decrease family admissions is the belief that the post-1965 immigrants—many of whom entered via kinship ties—are not good for the U.S. economy. This belief may partly reflect a reaction to the predominantly Asian and Hispanic post-1965 U.S. immigration versus the predominantly West-European pre-1965 immigration; the U.S. has a long history of both welcoming and being wary of new immigrants. ${ }^{3}$ We argue instead that an emphasis on entry earnings and a flawed methodology for measuring immigrant earnings growth (prominent in economic research and standard fare in economics textbooks) supports the spurious conclusion that the post-1965 immigrants have not benefited the U.S. economy.

\section{Measuring Immigrant Earnings Growth}

Prominent studies that conclude that the labor market “quality” of immigrants fell after 1965 focus on the entry earnings of immigrant men and rely upon an assumption that changes in

\footnotetext{
${ }^{3}$ In a letter dated May 9, 1753, Ben Franklin comments on German immigrants: “Those who come hither are generally of the most ignorant Stupid Sort of their own Nation... Not being used to Liberty, they know not how to make a modest use of it...they come in droves... they will soon so outnumber us...we will not be able to preserve our language... even our Government will become precarious.”
} 
the entry earnings of immigrant cohorts are unaccompanied by changes in earnings growth (e.g. Borjas, 1985, 1987, 1992a, b, 1994). Other common methodological issues also cause underestimates of immigrant earnings growth in these and other studies. Most economic analyses of immigrant earnings’ profiles hold level of schooling constant. Yet post-1965 adult immigrants have attended school at much higher rates than U.S. natives, of the same age, and continue to attend school, while working, years after their U.S. arrival (Duleep, Regets, Sanders, and Wunnava, 2014). Economists routinely exclude the self-employed from wage equations so as not to bias estimates of the return to education with returns to financial capital. By doing this, they exclude a major path of immigrant advancement. ${ }^{4}$ Similarly, excluding those with zero earnings (who may be investing in schooling or training) is necessary for regressions on the log of earnings, but misses the effects of large increases in immigrant labor force participation.

Using multiple censuses, Borjas observed a steep decline in the initial earnings of immigrant men, a decline that persists within age and education categories and is most apparent since the 1960's when U.S. immigration policy changed from a national-origins system, favoring West-European immigration, to a family-based policy. As measured by decennial census data, in 1969, immigrant men 25-54 who entered the United States between 1965 and 1970 earned 65\% of native men's earnings; in 1979, immigrants who entered in 1975-1980 earned 50\% of native's earnings; and in 1989, immigrants who entered in 1985-1990 earned 41\% of natives' earnings. Though dramatic, the importance of this decline depends on whether the initial disadvantage experienced by recent immigrants (relative to natives and relative to earlier immigrant cohorts) persists.

${ }^{4}$ Lofstrom (2002) finds including the self-employed reduces the immigrant-native earnings gap by $14 \%$. 
The methodology pioneered by Borjas (1985), and almost universally adopted in analyses of immigrant earnings trajectories, “captures” cohort differences by including a categorical (0-1) variable for each year-of-entry immigrant cohort. This allows entry earnings to change but assumes that the earnings growth rate of year-of-entry immigrant cohorts remains constant once observable variables, such as age and education, are accounted for.

[Figure 2 about here]

Figure 2 shows the actual entry earnings of the 1965-70, 1975-80, and 1985-90 cohorts as well as the actual earnings ten years later for the 1965-70 cohort. For the 1975-80 and 19851990 cohorts, earnings at the ten-year mark are projected assuming no change in earnings growth accompanied the decline in entry earnings. This creates a bleak picture of the ability of the more recent cohorts to assimilate as their initially low earnings, relative to the 1965-70 cohort, persist unabated.

A radically different picture emerges when the assumption of inter-cohort constancy in earnings growth is dropped. Allowing both entry earnings and earnings growth to change, Duleep and Regets (1994a, b, 1996c, 1997a, c, 2002) followed the entry cohorts of immigrants across decennial censuses. Using the 1980 census, we measured the 1979 earnings of immigrants, ages 25-54, who entered the United States between 1975 and 1980. With the 1990 census, we measured the 1989 earnings of the same cohort of immigrants—-those who entered the United States in 1975-1980 and were 35-64 years old in 1990. Similarly, using the 1970 and 1980 censuses, the entry earnings and earnings ten years later of immigrants who entered the country in 1965-1970 were measured. The earnings of comparably-aged U.S. natives were also measured to provide estimates of relative immigrant earnings growth. 
[Figure 3 about here]

These analyses reveal that as immigrants’ entry earnings decreased over time, their earnings growth increased. The increase in earnings growth is so great that by the time of the subsequent census, ten years later, the earnings of the more recent cohort nearly equals the relative earnings that earlier cohorts had achieved after 10 years. Despite a $23.4 \%$ drop in the initial earnings relative to natives between the 1965-1970 and the 1975-1980 immigrant entry cohorts, there is very little difference in their relative earnings by the time of the subsequent decennial census - $85 \%$ for the $1965-1970$ cohort and $84 \%$ for the $1975-1980$ cohort. $^{5}$ The true earnings trajectories of the post-1965 immigrants are not as shown in Figure 2, but as shown in Figure 3.

\section{Earnings Profiles and Admission Criteria}

The decline in immigrant entry earnings paired with the assumption of earnings-growth stationarity helped convince scholars that the 1965 family-reunification policy fostered a decline in the productivity of U.S. immigrants. Yet, post-1965 immigrants have high earnings growth, and over time their earnings growth has increased as their entry earnings decreased. Studies that follow individual U.S. immigrants (without imposing any relationship between entry earnings and earnings growth) confirm that recent immigrant men and women start with relatively low earnings but experience wage and earnings growth far exceeding that of earlier immigrant cohorts, or of U.S. natives (Duleep and Regets 1997b; Duleep and Dowhan 2002a, 2002b). ${ }^{6}$

\footnotetext{
${ }^{5}$ The effect is even more dramatic separating into age and education groups. In each case, the cohort with lower relative entry earnings surpasses the initially higher-earning immigrant cohort (Duleep and Regets, 2002).

${ }^{6}$ With longitudinal individual data, selective emigration can be removed as a spurious contributor to
} 
The inverse relationship between immigrant entry earnings and earnings growth also casts a more nuanced light on kinship versus employment-based immigration. Employmentbased immigrants should initially out-earn kinship-based immigrants: By the very nature of their admission, requiring an employer who wants to hire them, they have highly transferable skills to the United States. But family-based immigrants should have a higher propensity to invest in new human capital, hence higher earnings growth, than employment-based immigrants: Since employment-based immigrants enter the U.S. with skills linked to specific employment opportunities, the return to investing in new U.S. human capital is less and the opportunity cost higher than it is for family-based immigrants. Moreover, immigrants with U.S. family ties should be more permanent than immigrants lacking such ties; immigrants who plan to stay permanently in the U.S. will be more likely to invest in U.S. human capital. ${ }^{7}$

To test whether family admission (versus employment admission) negatively affects entry earnings and positively affects earnings growth, we used Public Use Sample microdata on working-age immigrant men from the 1990 census matched to INS data on admission criteria by year of admission and country of origin (Immigration and Naturalization Service, all years, 1975-1990). ${ }^{8}$ Exploiting variations in the percentage of immigrants admitted under specified criteria across country-of-origin/year-of-entry cohorts, we estimated the following equation:

$$
\mathrm{y}_{\mathrm{i}}=\alpha+\gamma_{1} \text { PerOcc }_{\mathrm{jk}}+\mathrm{X}^{\prime} ß_{1}+\left(\aleph_{2}+\Theta \mathrm{PerOcc}_{\mathrm{jk}}\right) \mathrm{YSM}+\varepsilon_{\mathrm{i}}
$$

earnings-growth estimates by following the same individuals over time. See Warren and Kraly (1985) for the study that alerted researchers to the importance of immigrant emigration.

${ }^{7}$ Immigrant men and women whose first earnings coincide with intent to stay have higher earnings growth than immigrants who earned in the U.S. for several years before deciding to stay permanently Duleep and Dowhan (2002a, b).

${ }^{8}$ For more details, see Duleep and Regets (1996b). 
where $\mathrm{y}_{\mathrm{i}}$ is the natural logarithm of the earnings of immigrant $\mathrm{i}$; $\mathrm{X}$ a vector of variables measuring age, age ${ }^{2}$, and education and $\beta_{1}$ the vector of corresponding coefficients; YSM years since migration; and PerOcc $\mathrm{jk}$ the percent of immigrants in country-of-origin group $\mathrm{j}$ and year-ofimmigration cohort k admitted via occupational skills. The complement of PerOcc is (primarily) the percent of family-admitted immigrants in each country-of-origin/year-since-migration group. We would expect $\gamma$ to be positive, reflecting the higher skill transferability of employment-based immigrants and $\Theta$ to be negative, reflecting the lower earnings growth of employment (versus kinship) immigrants. ${ }^{9}$

The estimated coefficients (Table 1, first column) on percent admitted via occupational skills and on the interaction term between this variable and years since migration indicate that as employment admissions increase, initial earnings increase, ${ }^{10}$ but earnings growth decreases. ${ }^{11}$ Stated another roughly equivalent way—as the percent of kinship admissions increases, immigrants' initial earnings decrease and earnings growth increases. Adding to the regression the percent of siblings admissions (Table 1, second column) reveals that the larger this percent, the greater immigrant earnings growth is: the estimated coefficient on the interactive term (PerSib x YSM) suggests that a 10 percentage-point increase in sibling admissions increases immigrant annual earnings by $1.06 \%$ per year, over and above the earnings-growth increase associated with family admissions in general.

[Table 1 about here]

\footnotetext{
${ }^{9}$ A negative coefficient on the YSM x PerOcc variable implies that family admissions are positively associated with immigrant earnings growth relative to occupational-skills admissions.

${ }^{10}$ The estimated coefficient is positive on Percent Occupational-Skills Admissions.

${ }^{11}$ The estimated coefficient is negative on Years Since Migration x Percent Occupational-Skills Admissions.
} 
These findings are robust. Similar results emerge with an analogous methodology estimated on earlier data (Duleep and Regets, 1992, 1996a), with a more sophisticated methodology estimated on more recent data (Duleep and Regets, 2014), and with estimations using longitudinal data on individuals (Jasso and Rosenzweig, 1995, DeSilva, 1996).

\section{Family-Based Immigrants and National Competitiveness}

Kinship immigrants experience higher earnings growth than employment immigrants, with the earnings growth being particularly high in cohorts with high siblings' admissions. The push to curtail family admissions, however, stems from a belief that employment-based immigrants improve national competitiveness whereas kinship immigrants do not. What does earnings growth have to do with national competitiveness?

Earnings growth reflects human-capital investment. Immigrant earnings patterns characterized by low initial earnings and high earnings growth are associated with high rates of schooling, training, and occupational change (Duleep and Regets 1999, 2002; Akresh 2007). That recent immigrants, who mostly enter via kinship ties, have higher earnings growth than U.S. natives ${ }^{12}$ means that recent immigrants are investing in new skills (human capital) at higher rates than U.S. natives. That kinship immigrants have higher earnings growth than employment immigrants means that kinship immigrants are investing in new skills at higher rates than employment immigrants.

Innovation, spurred in the U.S. by new and changing businesses, is the foundation of economic growth. New and changing businesses require people who are willing and able to

\footnotetext{
${ }^{12}$ Works showing that recent immigrant men and women have higher earnings growth than U.S. natives include Duleep and Regets (1994a, 1997a, 1997b, 2002) and Duleep and Dowhan (2002a, 2002b).
} 
acquire new human capital. The most important attribute that immigrants can bring to insure the U.S. economy's long-run vitality is a propensity to learn new skills, whether in response to the needs of emerging or changing businesses, or by starting a new business. Theoretically, because employment-based immigrants enter to fill specific jobs_-and are paid accordingly — they have no more incentive than U.S. natives to invest in new human capital. ${ }^{13}$ The low opportunity cost for a similarly educated kinship-based immigrant who could not initially transfer his homecountry human capital, paired with the value of this undervalued human capital for learning, makes pursuing further training an attractive option. Kinship-based immigrants—precisely because they lack specific skills immediately valued by the U.S. labor market—will have a higher propensity to invest in new human capital than U.S. natives or employment-based immigrants with comparable levels of schooling. ${ }^{14}$ An immigrant-admission policy focused on filling specific labor market needs may be less likely to foster a flexible labor force than a family-based policy.

\section{Siblings and Immigrant Business Formation}

In addition to providing a flexible labor force that facilitates new directions by U.S. natives, immigrants can be entrepreneurs themselves. Here, again, kinship-admitted immigrants_-particularly siblings_-play a productive role.

To examine the relationship between admission criteria and self-employment, we used the 1990 census-INS admissions data to measure correlations between the percent of each

\footnotetext{
${ }^{13}$ An important caveat: Immigrants regardless of their admission are likely less risk adverse than natives. This, in and of itself, would make them more likely than natives to pursue new career and training paths. Moreover, immigrants, particularly those from economically developing countries, may pursue any admission path (kinship or employment) to pursue a new career direction in the U.S.

${ }^{14}$ This prediction flows from a simple Immigrant Human Capital Investment (IHCI) model (Duleep and Regets 1999, 2002).
} 
country-of-origin/year-of-entry cohort that was self-employed and, respectively, the percent admitted via occupational skills and the percent admitted via the siblings' preference. No statistically significant correlation emerges between whether an immigrant is self-employed and the percent of his year-of-immigration/country-of-origin cohort admitted via occupational skills (Table 2). Yet, for all regions, a highly statistically significant, positive relationship exists between the propensity of individual immigrants to be self-employed and the percent of their cohort admitted via the siblings' category.

[Table 2 about here]

To further probe the relationship between admission criteria and immigrant selfemployment, we estimated the following model:

$$
\mathrm{P}(\text { SelfEmp })_{\mathrm{i}}=\alpha+\mathrm{X}^{\prime} \beta_{1}+\beta_{2} \mathrm{YSM}+\gamma_{1} \text { PerOcc }_{\mathrm{jk}}+\gamma_{2} \text { PerSib }_{\mathrm{jk}}+\varepsilon_{\mathrm{i}}
$$

where $\mathrm{P}(\text { SelfEmp })_{\mathrm{i}}$ is the probability that immigrant $\mathrm{i}$ is self-employed, PerOcc $\mathrm{jk}$ is the percent of immigrants in group $\mathrm{j}$ and cohort $\mathrm{k}$ admitted through the employment-preference categories, PerSib $_{\mathrm{jk}}$ is the percent of immigrants in group $\mathrm{j}$ and cohort $\mathrm{k}$ admitted through the siblingpreference category, YSM is years since migration, and the vector $\mathrm{X}$ includes age, age ${ }^{2}$, and seven education categories. ${ }^{15}$

Controlling for age, education, and years since migration, sibling admissions are negatively associated and employment admissions positively associated with the propensity to be self-employed for Europeans. However, for the two largest immigrant groups, Asians and Hispanics, employment admissions have either a negative or statistically insignificant effect on

\footnotetext{
${ }^{15}$ The reference category is $0-8$ years.
} 
the propensity to be self-employed whereas the siblings' effect is positive and large. Indeed, its effect on self-employment overshadows any other variable in the analysis (Table 3).

[Table 3 about here]

\section{Inadvertent Consequences of Removing Family-Admission Categories}

The debate about admissions based on family versus skills is often presented as a

dichotomy: Should the U.S. continue its primarily kinship-based policy or adopt a system that rewards needed skills? Yet skilled immigrants have families too. In considering which country to move to, will an emigrating scientist be more likely to choose a country where his family, including siblings, parents, and adult children, can also live, or a country where only certain family members are welcome?

Since the mid-twentieth century, the United States has become much less dominant in science and technology — around two-thirds of global R\&D is now performed outside the United States. For today's advanced degree holders, an international job search is normal, with career opportunities in multiple countries. In this setting, the openness of U.S. immigration policy affects the number and quality of the high-skilled workers we recruit. ${ }^{16}$ Currently, even U.S.educated doctorate holders, who may have been in the U.S. for a decade, would need a new visa to take a U.S. job. With job offers from multiple countries, the likelihood of obtaining visas for themselves and their family has to be an immediate part of their decision-making.

When immigrant scientists and engineers are asked why they came to the United States, family reasons dominate (Figure 4). Dividing by age and excluding persons who immigrated as children, family reasons are as important for scientists and engineers who migrated during

\footnotetext{
${ }^{16}$ See Regets $(2007,2008 a, b)$ for data and discussion of high-skilled international migration.
} 
working ages, as are job opportunities (Kannankutty and Burreli, 2007). A family-friendly policy may be one reason the United States has been able to attract the best and the brightest.

[Figure 4 about here]

Using the 1990 census-INS admissions data, we analyzed the effect on immigrant education levels of family-versus-employment admissions. ${ }^{17}$ As before, our explanatory variable PerOcc is the percentage of immigrants admitted via occupational skills in each year-ofentry/country-of-origin cohort and PerSib the percent of siblings' admissions in each cohort.

Not surprisingly—given that one of the occupational skills' categories admits professionals, scientists, and artists of exceptional ability—immigrant education levels positively correlate with the percent of immigrants admitted via occupational skills. Yet immigrant education levels also increase with sibling admissions (Table 4). These results persist controlling for age and years since migration and estimating the probability of having a college degree or higher or the probability of having a high school degree or higher (Table 4, bottom half). The results suggest that increasing occupation-based admissions and increasing sibling admissions increases immigrant education levels: immigrants who gain admission via occupational skills are followed by their siblings, who gain admission via the siblings' preference. If those who enter via occupational skills are highly educated, their siblings are likely highly educated.

[Table 4 about here]

Siblings following the footsteps of well-educated, occupationally-admitted immigrants would be most prevalent among immigrants from less economically developed countries with more limited employment opportunities for the highly educated than in the U.S.: other things

${ }^{17}$ This work is described in more detail in Duleep and Regets (1996b). 
equal, a college-educated brother or sister of a U.S. German immigrant would be less likely to migrate to the U.S. than the college-educated sibling of a Mexican immigrant. ${ }^{18}$ Indeed, education and percent sibling are negatively associated for Europe and generally positively associated for Asia and Central and South America (Table 4). ${ }^{19}$

\section{Limitations of the Occupation-based Admission System}

Proposals to increase U.S. immigrant skill levels often entail expanding current occupation-based admissions and decreasing family admissions, even though a less familyfriendly admission system may make the United States less attractive to potential immigrants with the most sought-after skills. There are also problems inherent to the occupation-based admission system.

Tailoring immigration to labor shortages sounds appealing, but is difficult in practice, and may not be even theoretically desirable. A movement from a shortage to a new market-clearing equilibrium can occur rapidly and trigger varied responses: a lack of workers can lead to an economic activity being altered, scaled back, or shutdown. "Vacancies" can be a very poor measure of demand for a skill. ${ }^{20}$

In the employment-based immigration system, a shortage is defined by an employer showing that a U.S. native or legal resident cannot be found to fill a position. Such a process

\footnotetext{
${ }^{18}$ Limited employment opportunity is broadly defined and includes the nature of employment.

${ }^{19}$ The exception to this pattern is the logit coefficient on Asia in the multivariate estimation for high school or higher.

${ }^{20} \mathrm{An}$ oft-proposed alternate measure of skill demand-whether wages in an occupation are rising-is also problematic because of heterogeneous skill levels within an occupational designation. During the "dotcom" boom, employment in computer occupations soared, but the average wages within computer occupations were stagnant as the new hires lowered the average skill levels within each occupation label. Moreover, with skill heterogeneity two workers in the same occupation can sometimes be complements rather than substitutes.
} 
requires a bureaucracy to oversee it. There is, however, no way to insure that employers are not using the occupational-skills immigration avenue to depress the wages of U.S. natives in those occupations.

Most studies of the impact of immigration on native wages find very small or even positive effects. However, to the extent that competition with natives is a policy concern, Lindsay Lowell (1996, 362) comments:

Skill-based immigrants, in part because their admission depends on formal links to U.S. employers... may enter directly into job competition with U.S. workers.... Conversely, the nature of the jobs that are initially filled by family-based immigrants, precisely because they are not as tightly linked to the primary labor market may mean that family-based immigrants compete less with U.S. workers. $^{21}$

The existing bureaucratic solution of using immigration to fill specific employer needs may also favor employers with political pull and established firms with the wherewithal to wade through bureaucratic waters.

\section{Alternatives to the Occupation-based Admission System}

Rather than increasing employment-based immigration at the expense of family-based immigration, a better approach would be to replace the fill-the-gap employment-based system, which requires a bureaucracy to execute an impossible mission, with an increased emphasis on an individual's education. Doing so could potentially increase the vital force that kinship-based immigrants provide the U.S. economy. ${ }^{22}$

\footnotetext{
${ }^{21}$ With matched census-immigrant admissions data, Sorensen (1996) estimates a small adverse effect of employment-based immigrants on the employment opportunities of U.S.-born whites and a small positive effect of kinship-based immigrants on the earnings of U.S.-born whites and blacks.

${ }^{22}$ Testing the IHCI model, Duleep and Regets (2002) and Duleep, Jaeger, and Regets (2012) find that the effect of low skill transferability on the propensity to invest in human capital increases with education.
} 
A minimally bureaucratic approach for increasing immigrant education levels in a way that promotes a flexible labor force is a student stay-on policy proposed by Bhagwati (1996, p. 328):

[An] option that would enable us to tap both skilled immigrants and to earn returns on our educational investment is to facilitate...foreign students staying on as immigrants. [By doing so] we can both eliminate the difficulties imposed on our foreign graduates as they struggle to stay here and resolve...the "crisis" that is the stuff of media articles on how in mathematics, sciences, and engineering, there is a large and growing body of foreign rather than native students. The distinction between foreign and native students would cease to matter... [if] the foreign students were seen as potential stay-ons in our society of immigrants.

The experiences of other countries elucidate how various policy alternatives could affect the educational composition of U.S. immigrants. Prior to 1993, the Canadian system departed from the U.S. system in that admission decisions for numerically restricted immigrants were based on a point system that primarily reflected characteristics believed to promote immigrant economic assimilation (youth, education, and English or French proficiency) as well as characteristics specifically tailored to prevailing occupational demand conditions. Yet, despite Canada’s greater emphasis on education in its admissions policy, Duleep and Regets (1992) found the education levels of Canadian and U.S. immigrants from the same region of origin were similar. $^{23,24}$

In 1993, Canadian immigration policy evolved from a system that sought to achieve multiple objectives, giving points to prospective immigrants for a wide variety of attributes, to

\footnotetext{
${ }^{23}$ Boyd (1976) suggests that the U.S. and Canadian systems were not, in practice, that different.

${ }^{24}$ Borjas (1993) stresses the Canadian skills-based system's effect on the source-country composition of immigration, which in turn affected immigrant education levels. His analysis attributes to the Canadian policy, imposed in the 1960s, what is likely due to the proximity of the U.S. to Central and South America and the historically higher European representation in Canadian immigration. The relevant question is whether - following imposition of Canada's skills-based admissions policy-European immigration fell less, and Central and South-American immigration increased less, in Canada than in the U.S. Although European immigration decreased from the 1960s to the 1970s in both countries, as a percentage of past immigration, it decreased more in Canada; Central and South- American immigration increased in Canada and decreased in the U.S.
} 
one that emphasized schooling, youthfulness, and English or French proficiency; the goal of tailoring immigration to fill various perceived employment needs was lessened. Beach and Green note:

...the weighting scheme [of the earlier system] ... focused on occupational needs in the economy at a particular point of time.... The occupational-based or gap-filling model used to guide admission was changed in the mid-nineties. In its place was substituted ...[a] human capital model perspective. Under this approach, specific occupational needs were reduced in the weighting scheme while additional points were awarded to education, age and language... This shift in weights in Canada signaled a move towards a longer-run view of immigration policy.

Beach and Green (2005) document an increase in the educational level of Canadian immigrants after the change. Theoretically, this is what one would expect. As more objectives in an immigrant admission point system are added to the educational enhancement objective, the effectiveness of the educational enhancement objective is reduced. By reducing its emphasis on immigration as a tool for filling specific perceived labor shortages, the educational objective of the Canadian point system was enhanced. ${ }^{25}$

\section{CONCLUSION}

Learning how immigrants fare in the labor market requires discerning from the available data their earnings growth. The U.S. study of immigrant earnings growth went from using a single cross section— to compare the earnings of recently-arrived and earlier immigrants (Chiswick, 1978, 1979), to using two censuses, potentially providing information on the earnings growth of year-ofentry cohorts identified in both censuses (Borjas, 1985), to using three censuses to measure how changes in the initial earnings of immigrant cohorts relate to changes in subsequent earnings growth (Duleep and Regets, 1994a, 2002). The analysis of immigrant adjustment with individual

\footnotetext{
${ }^{25}$ Quebec experienced less improvement in immigrant educational attainment than the rest of Canada (Parent and Worswick, 2003; Beach and Green, 2005); Quebec’s emphasis on French proficiency may have diluted the educational objective.
} 
longitudinal data has also flourished: Efforts include Social Security administrative records matched to survey data (Hu, 2000; Lubotsky, 2007; Duleep and Dowhan, 2002a, b); the New Immigrant Survey (Akresh, 2006, 2007, 2008; Jasso, Massey, Rosenzweig, and Smith, 2000); matched Current-Population-Survey data (Demombynes, 2002 and Duleep and Regets, 1997b); and longitudinal data in the Survey of Income and Program Participation (Hall and Farkas, 2008). ${ }^{26}$

As important as these data developments are, their analysis will misguide policy if analysts impose assumptions that distort or hide the earnings paths and human-capital investment trajectories of immigrants. Analysts who exclude or hold constant major paths of immigrant advancement, and impose the same earnings growth for immigrant cohorts starting with relatively high and relatively low earnings, will falsely conclude that immigrants who begin their U.S. lives at relatively low earnings experience limited mobility. Moreover, the tendency to focus on earnings levels and ignore earnings growth provides a myopic picture of how immigrants fare and how they contribute to the U.S. economy as it ignores an element most economists consider vital to economic growth— human capital investment.

A general belief that immigrants admitted via occupational skills are more economically productive than kinship-based immigrants has nurtured calls to reduce kinship-based immigration and increase employment-based immigration. However, recent immigrants—-the majority of whom enter the U.S. on family visas — are meeting the challenges of a U.S. labor market through melding high rates of post-migration human capital investment to their original skills, as evidenced in their high earnings growth. This fact has been hidden by a flawed methodology underlying much economic research.

\footnotetext{
${ }^{26}$ The earliest use of U.S. longitudinal individual data was Chiswick (1980).
} 
Rather than augmenting an underclass, the post-1965 immigrants are the most upwardly mobile of U.S. workers. This greatly benefits both immigrants and the U.S. economy. Their high propensity to invest in human capital likely contributes to economic vitality. ${ }^{27}$

In commenting about the presumed advantage of more educated immigrants, Bhagwati

(1996, p. 327) advances an uncommon perspective:

...if we were to consider the question instead in terms of who should be admitted so as to maximize the beneficial impact on those who are already the natives and residents of the United States, the answer must focus ... on whether the social marginal product in the United States of these alternative migrants exceeds their own private returns and, if so, which group offers the greater such excess.... Unfortunately, none of the advocates of skilled immigration have analyzed such issues.

Viewed through this lens, family-based immigrants may be more valuable to the U.S. than are employment-based immigrants.

Finally, family visas are an important complement to high-skilled visas, and only compete if they are placed under the same arbitrary cap. By adopting a less family-friendly admission system, the U.S. may lose both the dynamism associated with many family-based immigrants and also become less attractive to highly-skilled immigrants, who have families too.

\footnotetext{
${ }^{27}$ Other economic aspects of kinship admissions are not touched upon in this paper. The literature relevant to immigrant families and networks is much broader (Boyd, 1988). Using case-study evidence Gallo and Bailey (1996) consider the effects of family-based versus skills-based immigration on immigrant networks and their effects on immigrant economic adjustment: “...researchers and policymakers have only a weak understanding of the tradeoff between stronger skills and stronger networks, although the evidence suggests that effects on networks will reduce the economic benefits...of a shift to a skills-based system.”
} 


\section{References}

Akresh, I.R. 2006. “Occupational Mobility among Legal Immigrants to the United States.” International Migration Review, 40(4).

—, 2007. “U.S. Immigrants’ Labor Market Adjustment: Additional Human Capital Investment and Earnings Growth.” Demography, 44(4):865-881.

—, 2008. “Occupational Trajectories of Legal U.S. Immigrants.” Population and Development Review, 34(3):435-456.

Beach, Charles and Alan Green, 2005. "The Impacts of the Point System and Immigrant Class on Skill Characteristics of Immigrant Inflows: The Experience of Canada,” Immigration: Trends, Consequences and Prospects for the United States Conference,” September.

Beach, Charles, Alan Green, and Christopher Worswick, 2008. "Impacts of the Point System and Immigration Policy Levers on Skill Characteristics of Canadian Immigrants” in Immigration:Trends, Consequences and Prospects for the United States, ed. BR Chiswick, IZA/Elsevier, JAI:349-401.

Bhagwati, Jagdish, 1996. “U.S. Immigration Policy,” in H Duleep and PV Wunnava (editors), Immigrants and Immigration Policy: Individual Skills, Family Ties, and Group Identities, Greenwich, CT: JAI Press:323-334.

Borjas George, 1985. “Assimilation, Changes in Cohort Quality, and the Earnings of Immigrants.” Journal of Labor Economics 3:463-489.

—, 1987. "Self Selection and Immigrants.” American Economic Review 77:531-553.

—, 1992a. "National Origin and the Skills of Immigrants," in Immigration and the Work Force, GJ Borjas, RB Freeman, eds. Chicago:University of Chicago Press.

—, 1992b. "Immigration Research in the 1980s" in Research Frontiers in Industrial Relations and Human Resources, D Lewin, OS Mitchell, P Sherer, eds. Ithaca, N.Y.:Industrial Relations Research Association.

—, 1993. "Immigration Policy, National Origin, and Immigrant Skills,” in D Card and R Freeman (editors), Small Differences That Matter: Labor Markets and Income Maintenance in Canada and the United States, University of Chicago Press:21-44.

—, 1994. “The Economics of Immigration,” Journal of Economic Literature, December:16671717. 
Boyd, Monica, 1976. "Immigration Policies and Trends: A Comparison of Canada and the United States,” Demography, 13(February):82-102.

—, 1988. "Family and Personal Networks in International Migration,” International Migration Review, 23(88):638-70.

Chiswick, B.R. (1978) “The Effect of Americanization on the Earnings of Foreign-Born Men,” Journal of Political Economy, October:897-922.

Chiswick, B.R. (1979) “The Economic Progress of Immigrants: Some Apparently Universal Patterns,” in W. Fellner, ed., Contemporary Economic Problems. Washington, D.C.:American Enterprise Institute:359-99.

Chiswick, B.R. (1980) An Analysis of the Economic Progress and Impact of Immigrants, Department of Labor monograph, N.T.I.S. No. PB80-200454. Washington, DC:National Technical Information Service.

Demombynes, Gabriel M (2002) “Three Ways of Looking at Immigrant Wage Growth: Analysis with the 1993-1998 Current Population Survey” Institute for Labor and Employment, January, 2002

DeSilva, Arnold (1996) “Earnings of Immigrant Classes in the Early 1980’s in Canada: A Reexamination,” Human Resource Development Canada, 1996.

Duleep, Harriet and Daniel Dowhan. 2002a. "Insights from Longitudinal Data on the Earnings Growth of U.S. Foreign-born Men.” Demography 39:485-506.

—, 2002b. "Revisiting the Family Investment Model with Longitudinal Data: The Earnings Growth of Immigrant and U.S.-Born Women,” IZA Discussion Paper \#568, http://ftp.iza.org/dp568.pdf

Duleep, Harriet and Mark Regets. 1992. "Some Evidence on the Effect of Admission Criteria on Immigrant Assimilation,” in Immigration, Language and Ethnic Issues: Canada and the United States, BR Chiswick (ed.). Washington, D.C.:American Enterprise Institute:410-439.

—, 1994a. “The Elusive Concept of Immigrant Quality: Evidence from 1960-1980,” (1992 American Economic Association version), PRIP-UI-28, Washington, DC:Urban Institute.

—, 1994b. “Country of Origin and Immigrant Earnings,” PRIP-UI-31, Washington, DC:Urban Institute.

—, 1996a. “Admission Criteria and Immigrant Earnings Profiles,” International Migration Review, Summer. 
—, 1996b. "Family Unification, Siblings, and Skills,” in H Duleep and PV Wunnava (eds.), Immigrants and Immigration Policy: Individual Skills, Family Ties, and Group Identities, Greenwich, CT: JAI Press:219-244.

_, 1996c. "Earnings Convergence: Does it Matter Where Immigrants Come From or Why?" Canadian Journal of Economics, 29(April).

_, 1997a. "The Decline in Immigrant Entry Earnings: Less Transferable Skills or Lower Ability?” Quarterly Review of Economics and Finance, 37:189-208.

—, 1997b. "Measuring Immigrant Wage Growth Using Matched CPS Files.” Demography 34(2):239-249.

-, 1997c. "Immigrant Entry Earnings and Human Capital Growth," Research in Labor Economics, 16:297-317.

_, 1999. "Immigrants and Human Capital Investment," American Economic Review, May:186191.

_, 2002. “The Elusive Concept of Immigrant Quality: Evidence from 1970-1990,” IZA

Discussion Paper \#631, http://ftp.iza.org/dp631.pdf

_, 2014. "Immigrant Admission Categories and Earnings Growth: 1980-2008,” Working Paper.

Duleep, Harriet, David Jaeger and Mark Regets. 2012. "How Immigration May Affect the Entrepreneurship of Natives,” IZA Discussion Paper \#6677 http://ftp.iza.org/dp6677.pdf

Duleep, Harriet, Mark Regets, Seth Sanders, and Phanindra Wunnava. 2014. A New Look at Human Capital Investment: A Study of Asian Immigrants and Their Family Ties, forthcoming.

Enchautegui, Maria, 2013. "Evolution of Family Policy in the United States," www.oecd.org/els/mig/Enchautegui.pdf

Gallo, Carmenza and Thomas Bailey, 1996. "Social Networks and Skills-Based Immigration Policy,” in H Duleep and PV Wunnava (editors), Immigrants and Immigration Policy: Individual Skills, Family Ties, and Group Identities, Greenwich, CT: JAI Press:203-218.

Hall, Matthew and George Farkas. 2008. "Does Human Capital Raise Earnings for Immigrants in the Low-Skill Labor Market?” Demography, 45(3):619-639.

Hu, Wei-Yin, 2000. "Immigrant Earnings Assimilation: Estimates from Longitudinal Data," American Economic Review, May:368-72. 
Jasso, Guillermina; Massey, Douglas; Rosenzweig, Mark; Smith, James (2000) “The New Immigrant Survey Pilot,” Demography. 37(1):127-136.

Jasso G. and Rosenzweig, M. R. (1995) Do Immigrants Screened for Skills Do Better than Family-Reunification Immigrants? International Migration Review 29:85-111.

Kannankutty, Nirmala and Joan Burreli, 2007. "Why Did They Come to the United States? A Profile of Immigrant Scientists and Engineers.” NSF 07-324, June.

Lofstrom, Magnus, (2002) "Labor Market Assimilation and the Self-Employment Decision of Immigrant Entrepreneurs,” Journal of Population Economics, 15(1):83-114

Lowell, B. Lindsay. 1996. "Skilled and Family-Based Immigration: Principles and Labor Markets,” in H Duleep and PV Wunnava (editors), Immigrants and Immigration Policy: Individual Skills, Family Ties, and Group Identities, Greenwich, CT: JAI Press:353-371.

Lubotsky, D. (2007), “Chutes or Ladders? A Longitudinal Analysis of Immigrant Earnings,” Journal of Political Economy, 115(5):820-867

Parent, Daniel and Christopher Worswick. 2003. "Qualificaitons et Immigrations: Réforme de la Grille d’Admissions du Québec,” Research Paper, Department of Finance, Government of Québec.

Regets, Mark, 2008. The Science and Engineering Labor Force, National Science Board.

—, 2008. “Adapting to the New High-Skilled Migration,” Harvard International Review, 30(3).

—, 2007. Research Issues in the International Migration of Highly Skilled Workers, National Science Foundation.

Reimers, David M. 2013. "More Liberal than We Thought: A Note on Immediate Family Member Immigrants of U.S. Citizens,” The Journal of Policy History, 25(2):288-298.

Sorensen, Elaine. 1996. "Measuring the Employment Effects of Immigrants with Different Legal Statuses on Native Workers," in H Duleep and PV Wunnava (eds.), Immigrants and Immigration Policy: Individual Skills, Family Ties, and Group Identities, Greenwich, CT: JAI Press:245-264.

Warren, Robert and Ellen Percy Kraly. 1985. The Elusive Exodus: Emigration from the United States. Population Reference Bureau. 


\begin{tabular}{|l|c|c|}
\hline \multicolumn{2}{|c|}{$\begin{array}{c}\text { Table 1: Effect of Admission Criteria on Initial Earnings and } \\
\text { Earnings Growth }\end{array}$} \\
\multicolumn{2}{|c|}{$\begin{array}{c}\text { Log(Earnings) Regression, Working-age Immigrant Men, 1990 } \\
\text { (all coefficients are highly statistically significant) }\end{array}$} \\
\hline $\begin{array}{l}\text { Percent occupational skills } \\
\text { admissions }\end{array}$ & 3.4215 & 3.5189 \\
\hline Years since migration & .0569 & .0467 \\
\hline $\begin{array}{l}\text { Years since migration } \mathrm{x} \\
\text { Percent occupation }\end{array}$ & -.1087 & -.1333 \\
\hline $\begin{array}{l}\text { Years since migration } \mathrm{x} \\
\text { Percent siblings admissions }\end{array}$ & & .1065 \\
\hline \hline
\end{tabular}




\begin{tabular}{||l|c|c|c||}
\hline \hline \multirow{2}{*}{ Table 2: Admission Criteria and the Propensity to be Self-Employed: Correlation Coefficients, 1990} \\
\hline & Asia & $\begin{array}{c}\text { Central \& South } \\
\text { America }\end{array}$ & Europe \\
\hline $\begin{array}{l}\text { Percent occupational } \\
\text { skills }\end{array}$ & .0050 & -.0018 & .0006 \\
\hline \begin{tabular}{l} 
Percent siblings \\
\hline \hline
\end{tabular} & $.1335^{*}$ & $.0565^{*}$ & $.0453^{*}$ \\
\hline
\end{tabular}


Table 3: Logistic Model of Immigrant Self-Employment, 1990

\begin{tabular}{|c|c|c|c|}
\hline & Asia & $\begin{array}{c}\text { Central \& South } \\
\text { America }\end{array}$ & Europe \\
\hline Intercept & $-7.8395^{*}$ & $-6.4335^{*}$ & $-4.4680 *$ \\
\hline $\begin{array}{l}\text { Schooling: } \\
\text { 9-11 years } \\
\end{array}$ & $.3770 *$ & $.1861^{*}$ & $.2359 *$ \\
\hline 12 years & $.5007 *$ & $.2343 *$ & $.2781 *$ \\
\hline Some college & $.3646^{*}$ & $.4533^{*}$ & $.3732 *$ \\
\hline Bachelor's & $.2384 *$ & $.5239 *$ & .0865 \\
\hline Master's & -.0547 & $-.5835 *$ & -.0674 \\
\hline Professional degree & $.9565^{*}$ & $1.2590 *$ & $.6987 *$ \\
\hline Ph.D. & $-.6679 *$ & -.1383 & $-.8865 *$ \\
\hline Age & $.2017^{*}$ & $.1401 *$ & $.0737 *$ \\
\hline $\mathrm{Age}^{2}$ & $-.00208 *$ & $-.00137 *$ & $-.0008 *$ \\
\hline Years since migration & $.0757^{*}$ & $.0382^{*}$ & $.1154^{*}$ \\
\hline $\begin{array}{l}\text { Percent occupational } \\
\text { skills }\end{array}$ & $-.4282 *$ & .0752 & $.5854^{*}$ \\
\hline Percent siblings & $2.7850 *$ & $1.5436 *$ & $-.9151 *$ \\
\hline
\end{tabular}




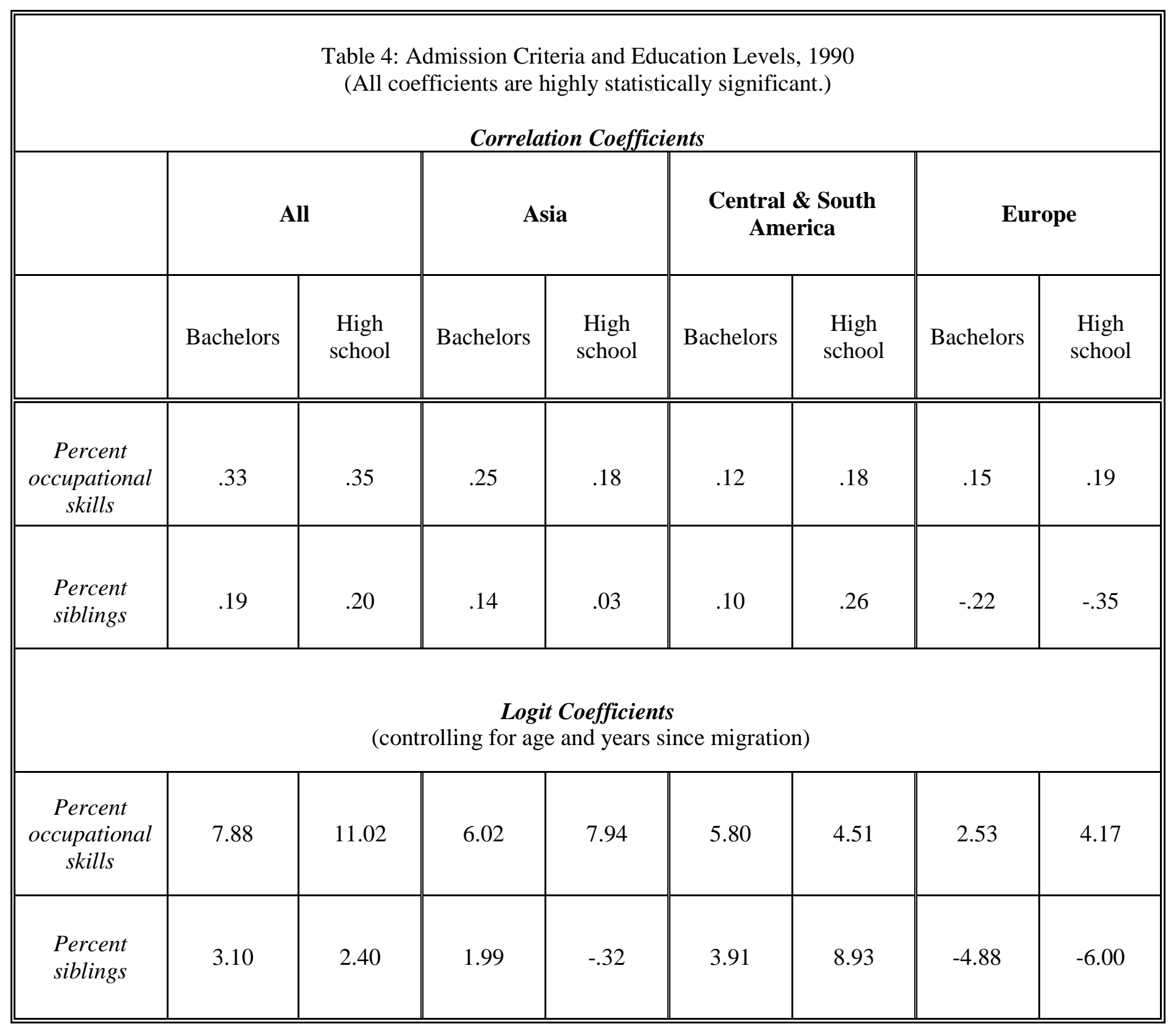


Figure 1:U.S. Immigration Policy

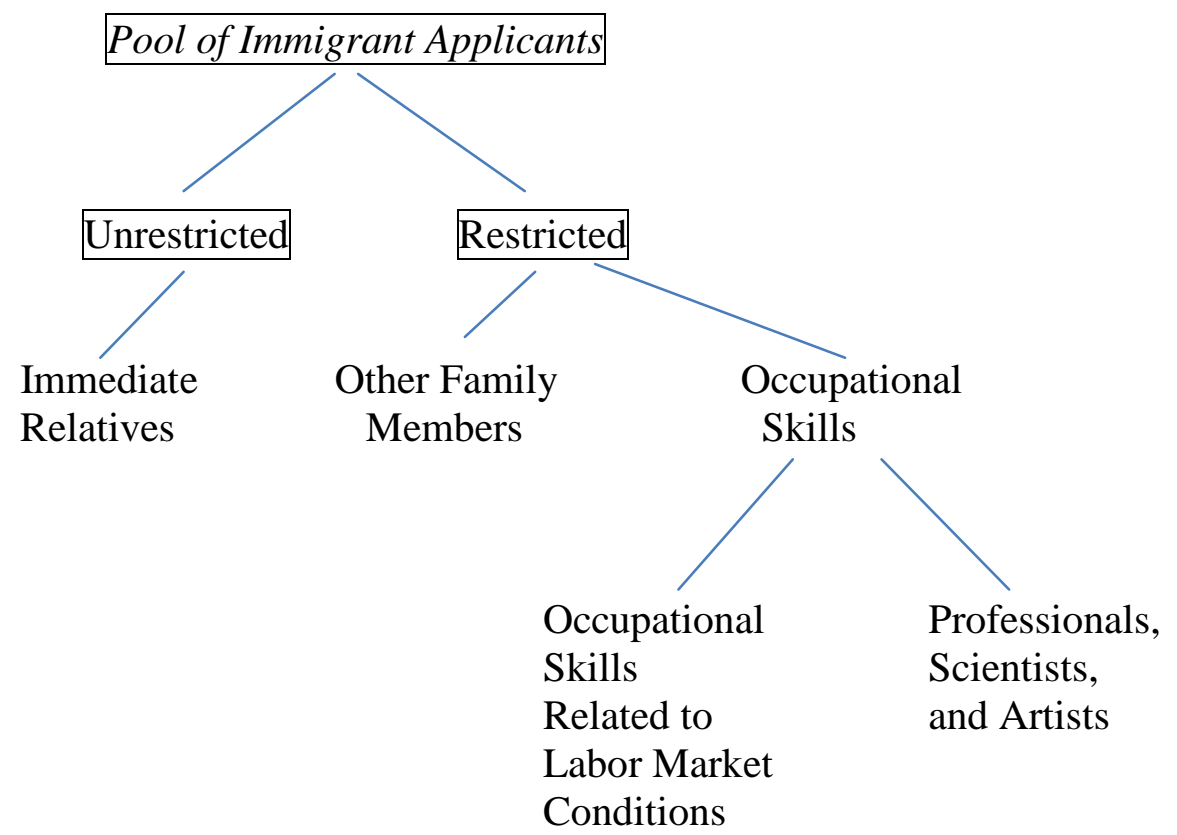




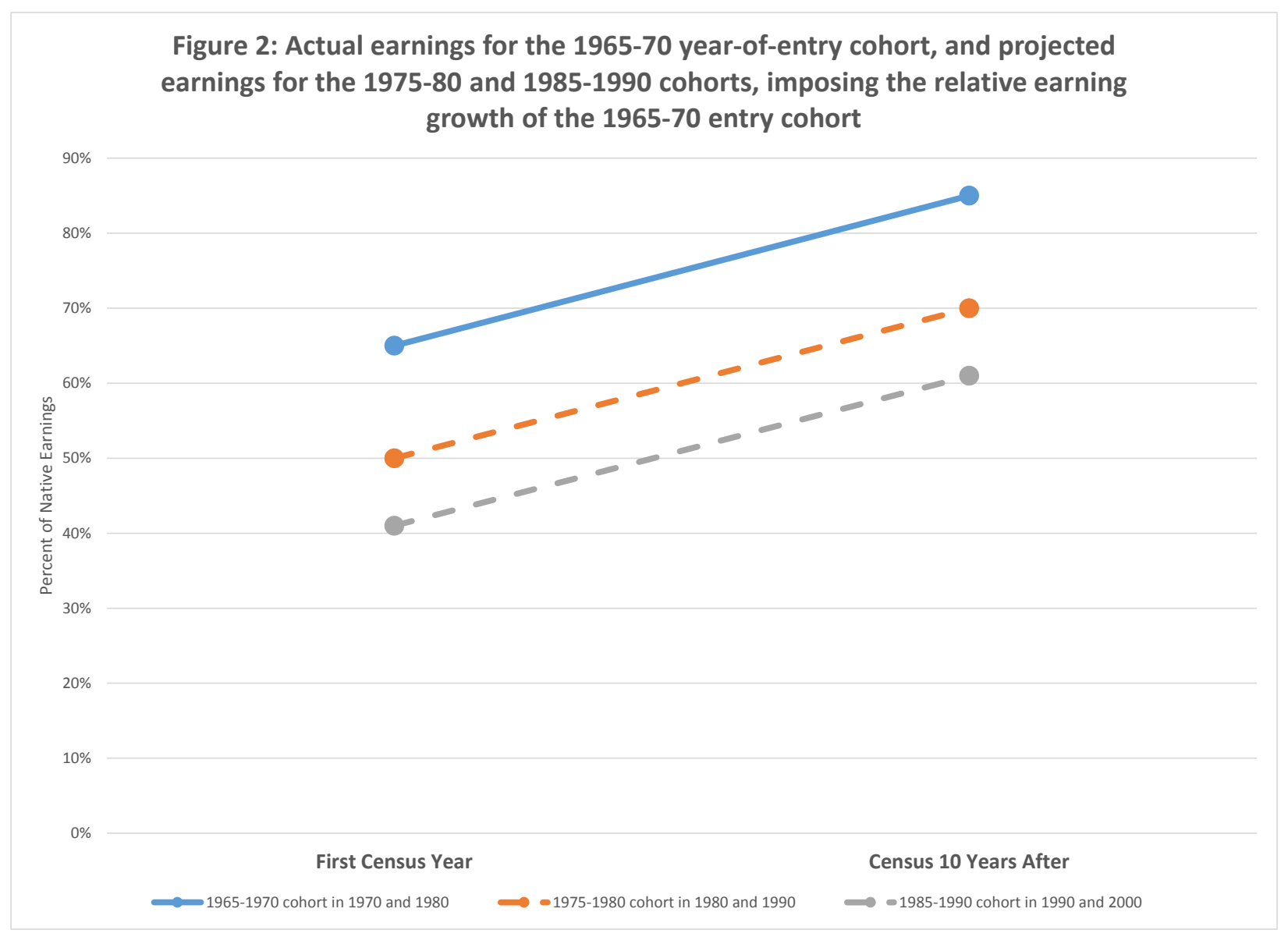




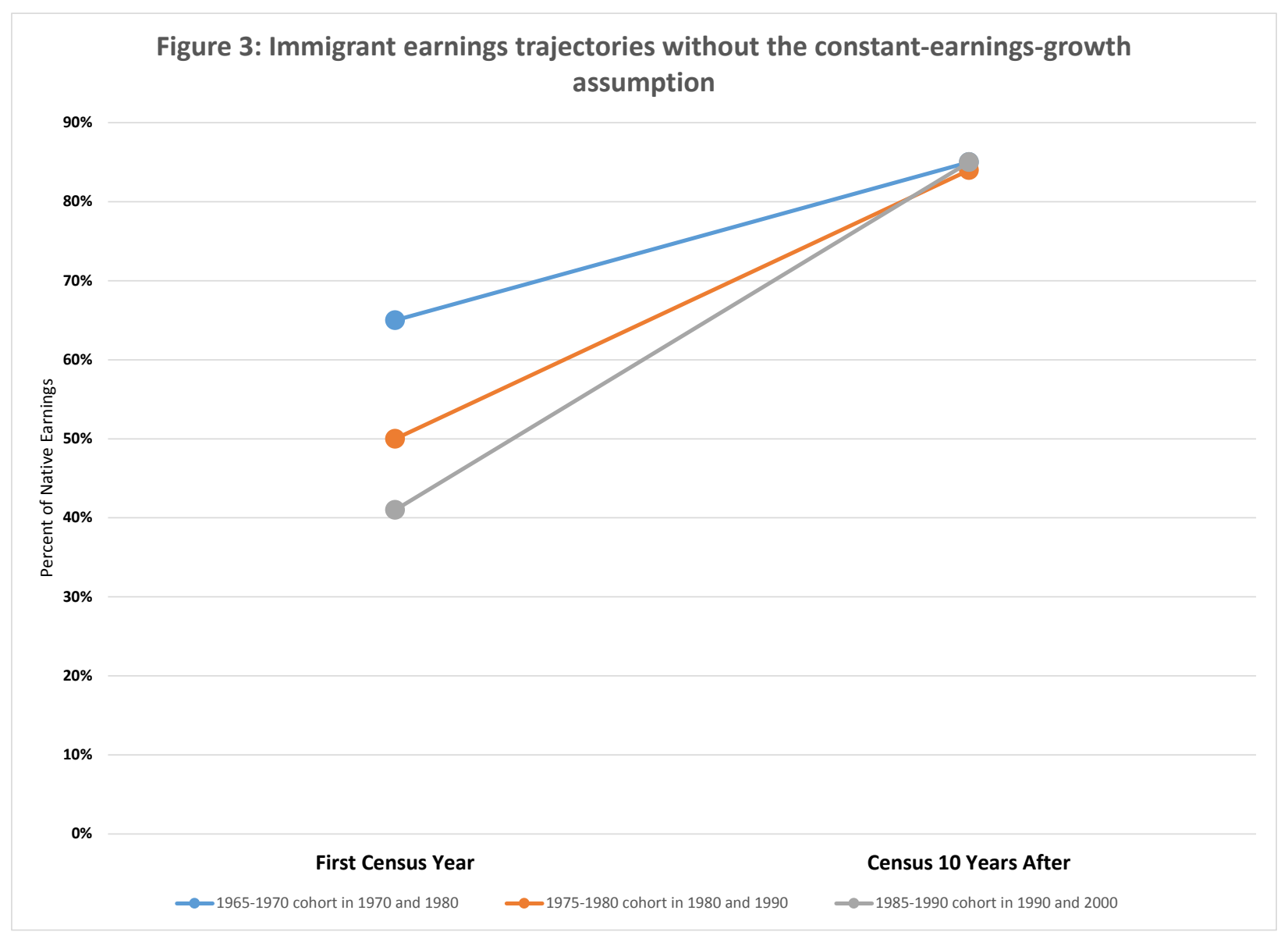


Figure 4:

Most important reason given by immigrant scientists and engineers for their decision to come to the United States: 2003

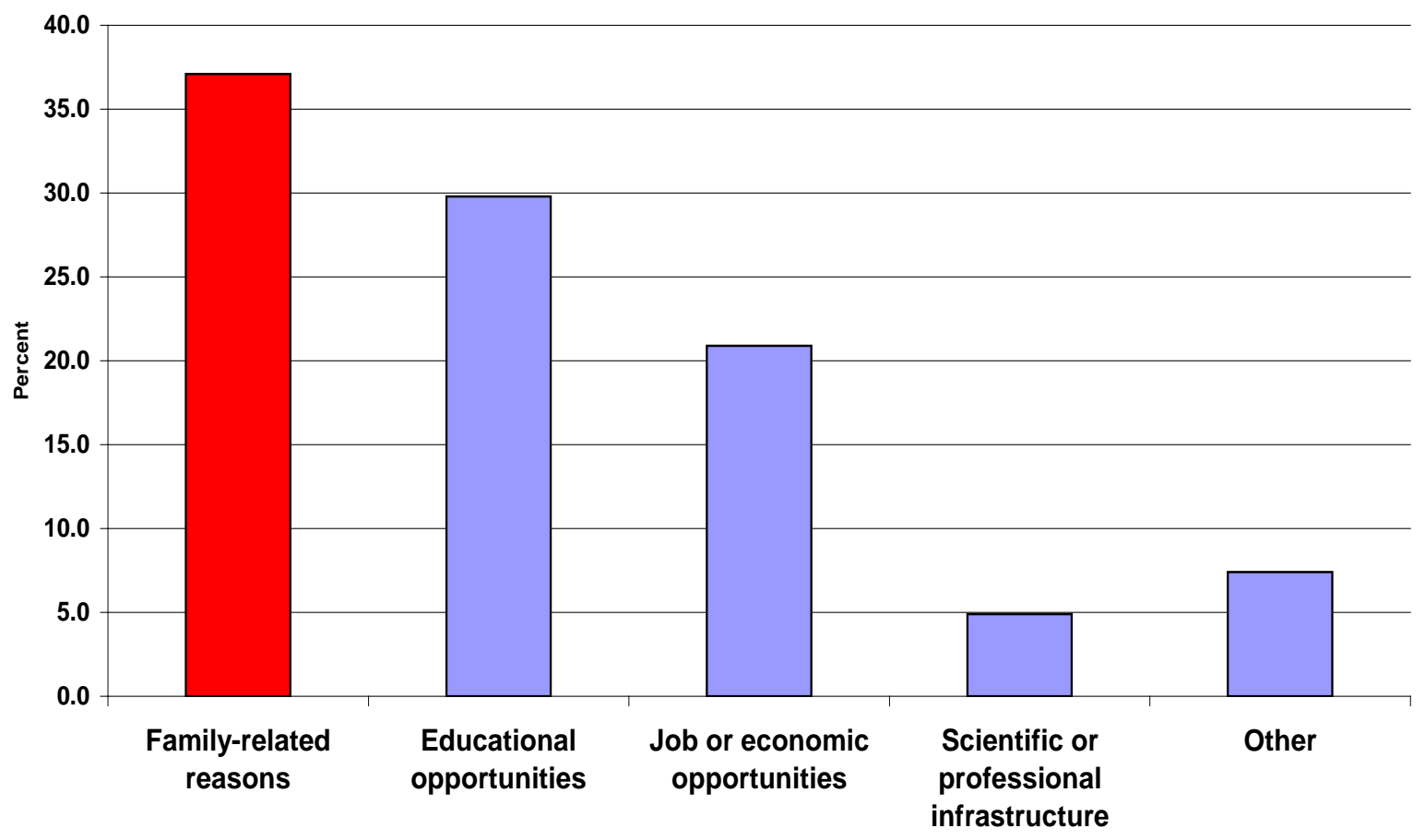

Source:Nirmala Kannankutty and Joan Burrelli, Why Did They Come to the United States? A Profile of Immigrant Scientists and Engineers, National Science Foundation, 2007 